\title{
An evaluation of the primary South African standard and guideline for the provision of water for firefighting
}

\author{
CB Mac Bean' and AA llemobade ${ }^{1 *}$ \\ 'School of Civil and Environmental Engineering, University of the Witwatersrand, Johannesburg, Private Bag 3, WITS 2050, South Africa
}

\begin{abstract}
In South Africa, as is mostly the norm globally, national legislation and guidelines specify that potable water distribution networks maintain the capacity to provide specified quantities of water for firefighting. This paper addresses the question: is the South African standard and guideline pertaining to fire-flow provision appropriate for firefighting and do these ensure the most efficient balance between providing sufficient fire protection and promoting sustainable water use? In answering this question, this study: (i) reviewed national and international design standards and guidelines; and (ii) captured and analysed 10 years of billable fire incident reports representing 3859 fire events within the City of Johannesburg. Highlights from the study include: inconsistencies in categories when comparing the SANS 10090 and The Red Book fire tables and violations (in The Red Book) of stipulated Minimum Fire Flows; over the 10 year period, $75 \%$ of fire incidents within the City of Johannesburg were extinguished using less than $6.6 \mathrm{~kL}$ of water - less than the capacity (6.9 kL) of the City's conventional pumping tanker during the period; $99.9 \%$ of fire incidents within the City were quenched using an average fire flow rate of less than $1200 \mathrm{~L} / \mathrm{min}$, which is the minimum hydrant flow rate for the lowest fire risk category in SANS 10090; and peak fire occurrence did not correspond with typical peak residential water use. Recommendations are proffered in respect of the above.
\end{abstract}

Keywords: firefighting water standard and guideline

\section{INTRODUCTION}

Water conservation has become a priority for many waterscarce countries around the world, including South Africa. With the majority of potable water supply to the public being delivered via municipal water systems, it is critical that these systems be designed, constructed and maintained in such a manner that they promote the most efficient use of water. Inseparable from the topic of efficient potable water use, is the efficient or inefficient provision of potable water for firefighting and the impact that this provision has on water distribution systems (WDSs) and water conservation.

A global consensus on the ideal design philosophy for providing water for firefighting remains to be established. Likewise, civil infrastructure standards linked to firefighting remain diverse and widely debated, as engineers face the challenge of balancing firefighting water provision against efficient water use. It is due to this complex trade-off between ensuring adequate supply of water for firefighting and minimizing water use that further research into this topic is critically needed.

In South Africa, the national standard (SANS 10090; SABS, 2003) and guideline (DHS and CSIR, 2019) recommend that potable water distribution mains have and maintain the capacity, both in flow $(\mathrm{L} / \mathrm{min})$ and pressure head $(\mathrm{m})$, to provide specified quantities of water for firefighting purposes. As a result, a dominant design constraint on WDSs is providing for fire flow, which is defined as the rate of flow of water required by the firefighting service for the extinguishing of fires (SABS, 2003).

Since fire flows significantly influence the sizing of a reticulated network, it is important that these requirements are defined as accurately as possible. It is interesting to note that the demand for water supplies during firefighting is believed,

${ }^{*}$ Corresponding author, email: adesola.ilemobade@wits.ac.za Received 23 August 2018; accepted in revised form 26 September 2019 by some, to be historically based on instinct and was strongly characterised by what was available rather than a technical analysis of what was needed (Law and Beever, 1995; Davis, 2000).

The condition of infrastructure, development of firefighting technologies and techniques, and the growth in fire safety awareness have all progressed with time and evolved dramatically since 1966 when the national codes for the provision of water for firefighting in South Africa were first published. Therefore, Van Zyl and Haarhoff (1997) recommend that the provision and requirements for fire flows be amended to reflect present conditions and technologies.

\section{Objectives}

This study addresses two objectives:

- To present an analysis of international and South African design standards and guidelines pertaining to water provision for firefighting

- To present actual fire flow data recorded in the City of Johannesburg, to compare this data with the primary South African standard and guideline values, and to make recommendations to guide future revisions of the primary South African design standard and guideline for the provision of water for firefighting

\section{South African standards and guidelines for fire flows}

Guidelines are intended to assist decision-making, whereas standards are enforceable absolute limits (Schlotfeldt, 1995 cited in CSIR, 2005). The national standard (also termed 'code') for the provision of water for firefighting in South Africa titled 'Community protection against fire' was first published in 1966 (SABS 090) and revised in 1972 (SABS, 1972). This code was compiled with the assistance of organizations from the UK, USA, Canada, New Zealand and Germany (Van Zyl and Haarhoff, 1997). A notable feature of this code is the absence of minimum water pressures for both water provision and the pumping ability 
of response units during a firefighting event. A summary of fire flow values within the most recent edition of this standard (i.e. SANS 10090: SABS, 2003) is shown in Table 1.

A separate national code, SANS 10252-1:2016 (SABS, 2016) titled 'Water supply and drainage for buildings Part 1: Water supply installations for buildings' addresses design pressures and flows for fire installations. A minimum provision of $30 \mathrm{~L} /$ min per fire hose reel and $1200 \mathrm{~L} / \mathrm{min}$ per hydrant is stipulated without any reference to fire risk categories. This code neither refers to SANS 10090 nor provides as much detail as it does. However, SANS 10252-1 stipulates that a minimum pressure of $300 \mathrm{kPa}$ must be maintained in hoses and hydrants.

Another industry-recognised reference that provides guidance on firefighting is the recently released Red Book (DHS and CSIR, 2019) titled The Neighbourhood Planning and Design Guide (Red Book): Creating Sustainable Human Settlement. The Red Book (DHS and CSIR, 2019) is an updated version of the CSIR (2005) Guidelines for Human Settlement Planning and Design. In contrast to the CSIR (2005) firefighting guidelines, The Red Book (DHS and CSIR, 2019) references the SABS 10090 (2003) code. The Red Book's fire flow values are presented in Table 2.

A notable distinction between SANS 10090 (SABS, 2003) and The Red Book (DHS and CSIR, 2019), apart from the different values they stipulate, is their differing fire risk categories. The Red Book presents a single set of fire risk categories to which all its various recommendations are related.
SANS 10090, however, presents two categories. The first is titled, 'Fire Risk Category', and the second, which is a subset of the first, is titled, 'Possible Fire Sizes'. The 'Possible Fire Sizes' category is used exclusively to determine 'Minimum Fire Flow' rates. An adverse consequence of having two categories in the SANS 10090 is that the Minimum Fire Flow and the Minimum Hydrant Flow are determined from different Fire Risk Categories, despite the fact that both are within the same table and connected. By way of example, an affluent residential area (Category C) where houses are spaced further than $30 \mathrm{~m}$ apart (Category D1) would have SANS 10090 recommend two Minimum Hydrant Flows of $2000 \mathrm{~L} / \mathrm{min}$ (Category C) and $1200 \mathrm{~L} / \mathrm{min}$ (Category D1) and two Minimum Fire Flows of $6000 \mathrm{~L} / \mathrm{min}$ (Category C) and $1900 \mathrm{~L} / \mathrm{min}$ (Category D1).

In addition to the above matter, some violations arise when employing Minimum Fire Flow values from The Red Book. The Red Book, which is a guideline that is intended to assist decision-making, should not, without reasonable justification, violate standards (in this instance, SANS 10090), which present enforceable absolute minimum limits (Schlotfeldt, 1995 cited in CSIR, 2005). All fire flow values in The Red Book are less than the values stipulated in SANS 10090 for similar fire risk categories. An example of this violation is seen in the first two fire risk categories in both documents - The Red Book recommends a fire flow of $6000 \mathrm{~L} / \mathrm{min}$ for the 'high risk' category and $3000 \mathrm{~L} / \mathrm{min}$ for the 'moderate risk 1' category; SANS 10090, on the other hand, stipulates $13000 \mathrm{~L} / \mathrm{min}$ and

Table 1. SANS 10090 fire flow summary (SABS, 2003)

\begin{tabular}{|c|c|c|c|c|c|c|c|c|c|}
\hline \multicolumn{10}{|c|}{ Fire risk category } \\
\hline \multicolumn{2}{|l|}{ A } & \multicolumn{2}{|r|}{ B } & $\mathrm{C}$ & \multicolumn{3}{|c|}{$\mathrm{D}$} & \multicolumn{2}{|c|}{$E$} \\
\hline \multicolumn{2}{|c|}{$\begin{array}{l}\text { Central business } \\
\text { districts and extensive } \\
\text { commercial and } \\
\text { industrial areas } \\
\text { normally found in cities } \\
\text { and large towns (areas } \\
\text { where the risk to life } \\
\text { and property due to fire } \\
\text { occurrence and spread } \\
\text { is likely to be high). }\end{array}$} & \multicolumn{2}{|c|}{$\begin{array}{l}\text { Limited central business } \\
\text { districts, smaller commercial } \\
\text { or industrial areas normally } \\
\text { associated with small towns } \\
\text { and decentralized areas } \\
\text { of cities and large towns } \\
\text { (areas where the risk to life } \\
\text { and property due to fire } \\
\text { occurrence and spread is } \\
\text { likely to be moderate). }\end{array}$} & $\begin{array}{l}\text { Residential areas } \\
\text { of conventional } \\
\text { construction. }\end{array}$ & \multicolumn{3}{|c|}{$\begin{array}{l}\text { Rural areas of limited } \\
\text { buildings and remote from } \\
\text { urban areas. } \\
\text { D1: Houses }>30 \mathrm{~m} \text { apart } \\
\text { D2: Houses } 10.1 \mathrm{~m} \text { to } 30 \mathrm{~m} \\
\text { apart } \\
\text { D3: Houses } 3 \mathrm{~m} \text { to } 10 \mathrm{~m} \\
\text { apart } \\
\text { D4: Houses }<3 \mathrm{~m} \text { apart }\end{array}$} & \multicolumn{2}{|c|}{$\begin{array}{l}\text { Special risk areas. Individual } \\
\text { areas requiring a pre- } \\
\text { determined attendance over } \\
\text { and above the predominant } \\
\text { risk category in an area. } \\
\text { Includes large shopping/ } \\
\text { entertainment centres, } \\
\text { informal settlements, } \\
\text { harbours, hospitals, prisons, } \\
\text { large airport buildings and } \\
\text { petrochemical plants. }\end{array}$} \\
\hline \multicolumn{10}{|c|}{ Provision of water for firefighting } \\
\hline \multicolumn{4}{|c|}{ Weight of response at fires } & \multicolumn{3}{|c|}{ Minimum fire flow } & \multicolumn{3}{|c|}{ Fire hydrants } \\
\hline $\begin{array}{l}\text { Fire risk } \\
\text { category }\end{array}$ & $\begin{array}{c}\text { Minimum } \\
\text { number of } \\
\text { pumping units }\end{array}$ & $\begin{array}{l}\text { Minimum } \\
\text { manning } \\
\text { level per } \\
\text { appliance }\end{array}$ & $\begin{array}{l}\text { Minimum } \\
\text { pumping } \\
\text { capacity of each } \\
\text { unit (L/min) }\end{array}$ & $\begin{array}{l}\text { Possible } \\
\text { fire sizes }\end{array}$ & & $\begin{array}{l}\text { Flow In } \\
\text { (L/min) }\end{array}$ & $\begin{array}{c}\text { Minimum } \\
\text { hydrant } \\
\text { flow } \\
\text { (L/min) }\end{array}$ & $\begin{array}{l}\text { Max. } \\
\text { distance } \\
\text { between } \\
\text { hydrants } \\
\text { (m) }\end{array}$ & $\begin{array}{c}\text { Maintenance } \\
\text { Intervals }\end{array}$ \\
\hline A & 2 & 5 & 3850 & \multicolumn{2}{|c|}{$\begin{array}{l}\text { Non-residential buildings } \\
\text { with divisions not greater } \\
\text { than } 5000 \mathrm{~m}^{2}\end{array}$} & 13000 & 2000 & 85 & Annually \\
\hline B & 2 & 4 & 3850 & \multicolumn{2}{|c|}{$\begin{array}{l}\text { Non-residential buildings } \\
\text { having divisions not } \\
\text { greater than } 2500 \mathrm{~m}^{2}\end{array}$} & 9000 & 2000 & 120 & Biennially \\
\hline C & 1 & 4 & 2250 & \multicolumn{2}{|c|}{$\begin{array}{l}\text { Non- residential premises } \\
\text { not greater than } 1250 \mathrm{~m}^{2}\end{array}$} & 6000 & 2000 & 200 & Triennially \\
\hline D1 & \multirow{4}{*}{1} & \multirow{4}{*}{4} & \multirow{4}{*}{2250} & Houses $>30 \mathrm{~m}$ apart & & 1900 & 1200 & 300 & \multirow{4}{*}{ Triennially } \\
\hline D2 & & & & $\begin{array}{l}\text { Houses } 10.1 \mathrm{~m} \text { to } 30 \mathrm{~m} \\
\text { apart }\end{array}$ & & 2850 & 1200 & 200 & \\
\hline D3 & & & & Houses 3-10 m apart & & 3800 & 1400 & 200 & \\
\hline D4 & & & & Houses $<3 \mathrm{~m}$ apart & & 5700 & 2000 & 200 & \\
\hline$E$ & * As determine & d by individu & ual risk assessment & & & & & & Annually \\
\hline
\end{tabular}


Table 2. The Red Book (DHS and CSIR, 2019) fire flow values

\begin{tabular}{|c|c|c|c|c|c|c|c|c|}
\hline \multirow{3}{*}{$\begin{array}{l}\text { Risk } \\
\text { classification }\end{array}$} & \multirow{3}{*}{$\begin{array}{c}\text { Maximum } \\
\text { hydrant spacing }\end{array}$} & \multirow{3}{*}{$\begin{array}{c}\begin{array}{c}\text { Duration of } \\
\text { design fire } \\
\text { flow (h) }\end{array} \\
\text { Red Book: } \\
\text { Table J.18 }\end{array}$} & \multicolumn{2}{|c|}{ Total fire flow } & \multicolumn{2}{|c|}{$\begin{array}{l}\text { Minimum flow } \\
\text { at one hydrant }\end{array}$} & \multirow{2}{*}{$\begin{array}{l}\text { Minimum } \\
\text { pressure at } \\
\text { fire node }(\mathrm{m})\end{array}$} & \multirow{2}{*}{$\begin{array}{l}\text { Minimum } \\
\text { pressure at rest } \\
\text { of the system (m) }\end{array}$} \\
\hline & & & $(\mathrm{L} / \mathrm{s})$ & (L/min) & $(\mathrm{L} / \mathrm{s})$ & (L/min) & & \\
\hline & & & \multicolumn{6}{|c|}{ Red Book: Table J.17 } \\
\hline $\begin{array}{l}\text { High risk: } C B D \text { and high } \\
\text { risk industrial }\end{array}$ & \multirow{4}{*}{$\begin{array}{l}200 \mathrm{~m} \text { (or as } \\
\text { otherwise } \\
\text { required by } \\
\text { the local fire } \\
\text { department) }\end{array}$} & 6 & 100 & 6000 & 25 & 1500 & 15 & 5 \\
\hline $\begin{array}{l}\text { Moderate risk } 1 \text { : } \\
\text { Industrial, business, } \\
\text { high-rise flats } \geq 4 \text { storeys }\end{array}$ & & 4 & 50 & 3000 & 25 & 1500 & 15 & 5 \\
\hline $\begin{array}{l}\text { Moderate risk } 2 \text { : Cluster } \\
\& \text { low-income housing, } \\
\text { high rise flats } \leq 3 \text { storeys }\end{array}$ & & 2 & 25 & 1500 & 25 & 1500 & 10 & 5 \\
\hline $\begin{array}{l}\text { Low risk: Single } \\
\text { residential housing }\end{array}$ & & 1 & 15 & 900 & 15 & 900 & 10 & 5 \\
\hline
\end{tabular}

$9000 \mathrm{~L} / \mathrm{min}$, respectively, for Categories A and B. This paper recommends a uniform category for both documents and Minimum Fire Flows that are consistent with analysed data.

\section{International standards and guidelines for fire flows}

Across the world, many methods have been developed to calculate fire flows. These methods generally form the basis on which fire protection codes, such as those discussed above, are established. These methods regulate the design of various WDS features such as: - Spacing of fire hydrants

- Minimum size of reticulation pipes

- Minimum flow rates and pressures

- Storage requirements and flow durations

In a report conducted by The Fire Protection Research Foundation, titled 'Evaluation of fire flow methodologies', 16 fire flow calculation methods were evaluated. The methods identified were from the USA, UK, France, Germany, the Netherlands, New Zealand, and Canada. Eleven of the methods address pre-incident infrastructure/building planning (see (a) below) and five are best suited for on-scene firefighting (see (b) below) (Benfer and Scheffey, 2014): (a) Infrastructure/building planning: These methods are necessarily predictive in nature, are more complicated and involve several steps and multiple calculations. Typical variables accounted for include: building construction, occupancy, fire size, heat release and sprinkler contribution. The inclusion of a variety of variables enables adjustments to be made to the building type or protection features (e.g. adding a sprinkler system) in order to reduce the fire flow.

(b) On-scene firefighting: These methods, by comparison, are much simpler, allowing fire fighters on the scene to assess whether they need more hose lines or apparatus to fight the fire. They typically consist of one equation with one independent variable - either the volume or area of the fire. The 16 fire flow calculation methods were simulated for two differently sized non-residential buildings and two differently sized single-family residential buildings. Their study included both sprinklered and non-sprinklered calculations.

Figure 1 shows the fire flow requirements for a non-sprinklered, non-residential building of $50000 \mathrm{ft}^{2}\left(4645 \mathrm{~m}^{2}\right)$.

To compare the primary South African fire flow standard (SANS 10090:2003, SABS, 2003) and guideline (The Red Book, 2019) with the 16 shown on Fig. 1, the Minimum Fire Flow

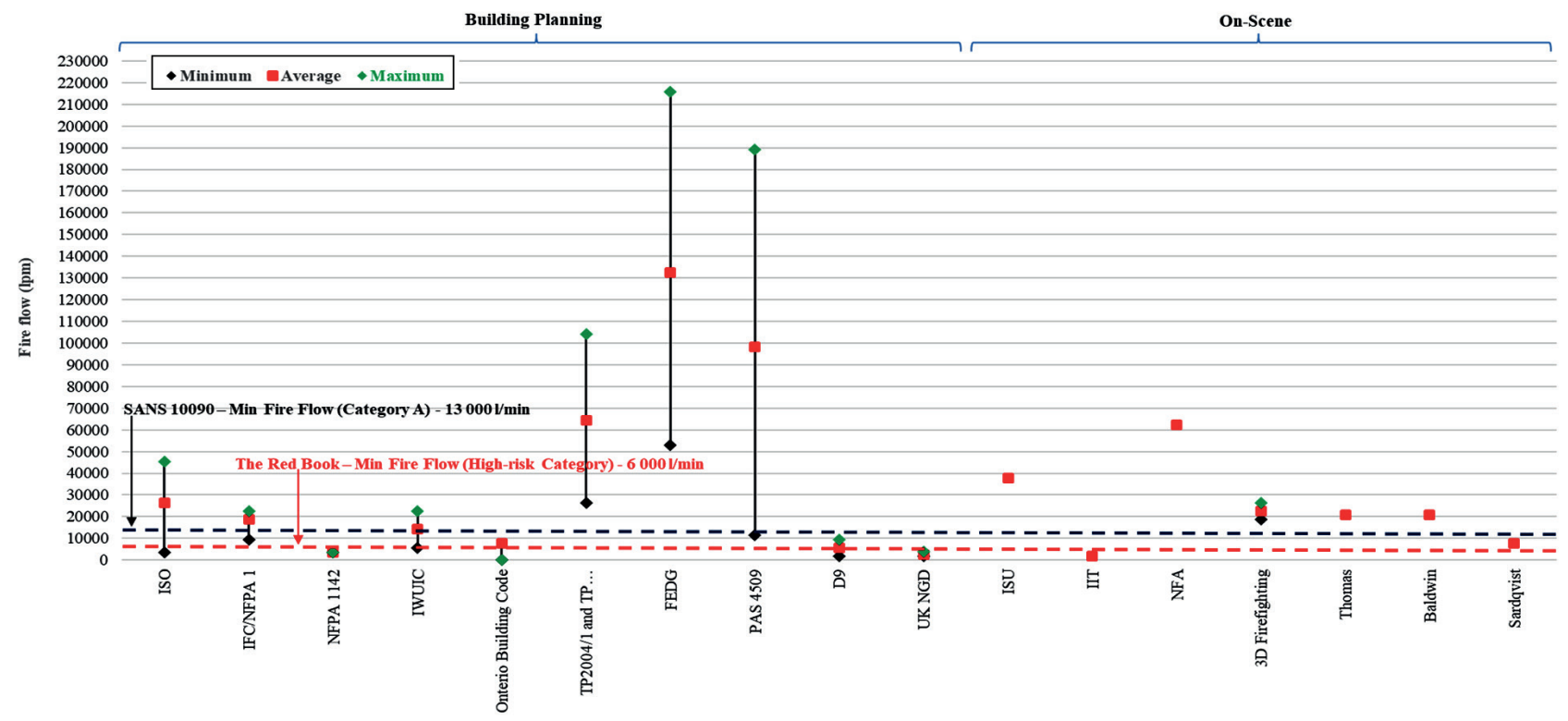

Figure 1. Fire flow requirements for a non-sprinklered, non-residential building of $4645 \mathrm{~m}^{2}$ (Benfer and Scheffey, 2014) 
requirements for a simlar structure, as defined in SANS 10090 and The Red Book, are superimposed on the results presented in the figure. It is important to note that the SANS 10090 fire flow values presented in Figs 1 and 2 do not explicitly deal with a single incident. However, as expressed in SANS 10090 (SABS, 2003) clause 11.4.1: 'The required fire flow should be available to the firefighting team on arrival at the fire.' It is thus assumed that the comparison made below is fair. Where applicable, both the Minimum Fire Flow and Minimum Hydrant Flow for SANS 10090 and The Red Book are shown in Figs 1 and 2.

Employing the SANS 10090 (2003) 'Possible Fire Sizes' category 'Non-residential buildings with divisions not greater than $5000 \mathrm{~m}^{2}\left(53800 \mathrm{ft}^{2}\right)$ ', a Minimum Fire Flow of $13000 \mathrm{~L} / \mathrm{min}$ is required (Fig. 1). In the figure, the SANS 10090 requirement falls within the ranges of the ISO, IFC/NFPA 1 , and the IWUIC Building Planning methods but is, for several of the other methods, several orders of magnitude lower. The Minimum Fire Flow requirement in The Red Book for the 'high risk' category (which is a similar category to the SANS 10090 category above) is $6000 \mathrm{~L} / \mathrm{min}$. The corresponding Minimum Hydrant Flow for SANS 10090 and The Red Book are $2000 \mathrm{~L} / \mathrm{min}$ and $1500 \mathrm{~L} / \mathrm{min}$, respectively.

It is seen from Fig. 1 that the range of possible fire flows is large, not only when comparing the various methods, but also within some ranges. The FEDG and PAS 4509 methods have the largest ranges. Furthermore, as can be seen in Fig. 1 , the Building Planning methods tend to recommend fire flows that are higher than the on-scene methods. many of the on-scene firefighting methods do not incorporate sprinkler protection systems in their calculations (Benfer and Scheffey, 2014).

Figure 2 shows the sprinklered and non-sprinklered fire flow values for a residential building of $3500 \mathrm{ft}^{2}\left(325 \mathrm{~m}^{2}\right)$.

Employing the SANS 10090 Risk Category D1 - 'Houses $>30 \mathrm{~m}$ apart', a Minimum Fire Flow of $1900 \mathrm{~L} / \mathrm{min}$ and a Minimum Hydrant Flow of $1200 \mathrm{~L} / \mathrm{min}$ are required. Employing The Red Book 'low risk' category, the Fire Flow and the Minimum Hydrant Flow are each 900 L/min.
For residential buildings fitted with sprinklers, it is worth noting that 12 out of the 18 Benfer and Scheffey (2014) methodologies shown on Fig. 2 required the same fire flow as non-sprinkler fitted buildings. However, as seen in Fig 1 and 2, Minimum Fire Flow requirements vary greatly across many countries.

\section{METHODS}

\section{Fire incident reports within the City of Johannesburg}

A fire incident report (or call slip) is a physical document that is filled out and submitted to the central Emergency Management Services (EMS) headquarters after each fire incident attended to by the fire brigade. Only billable (i.e. incidents that the fire department charges the property owner for services rendered) fire incident reports are digitally captured in spreadsheets by the EMS. Billable fire incident reports are best explained by sections 10.1 and 10.2 (Fees) of the Fire Brigade Services Act No. 99 (RSA, 1987). These sections (listed below) outline the basis on which the local fire department may charge for services rendered:

(1) A controlling authority may, subject to any condition contemplated in section 11(2)(a), determine the fees payable by a person on whose behalf the service of the controlling authority is applied-

(a) for the attendance of the service;

(b) for the use of the service and equipment; or

(c) for any material consumed.

(2) A person on whose behalf, in the opinion of the chief fire officer concerned, a service of a controlling authority has been employed, may in writing be assessed by that chief fire officer for the payment of the fees referred to in subsection (1) or any portion thereof.

It is the above billable incidents that have been consolidated and presented in this paper. In these reports, details captured include the duration of the call out, the quantity of water used, and the appliances used during the incident (see an example in Table 3). On-site calculations are carried out to estimate

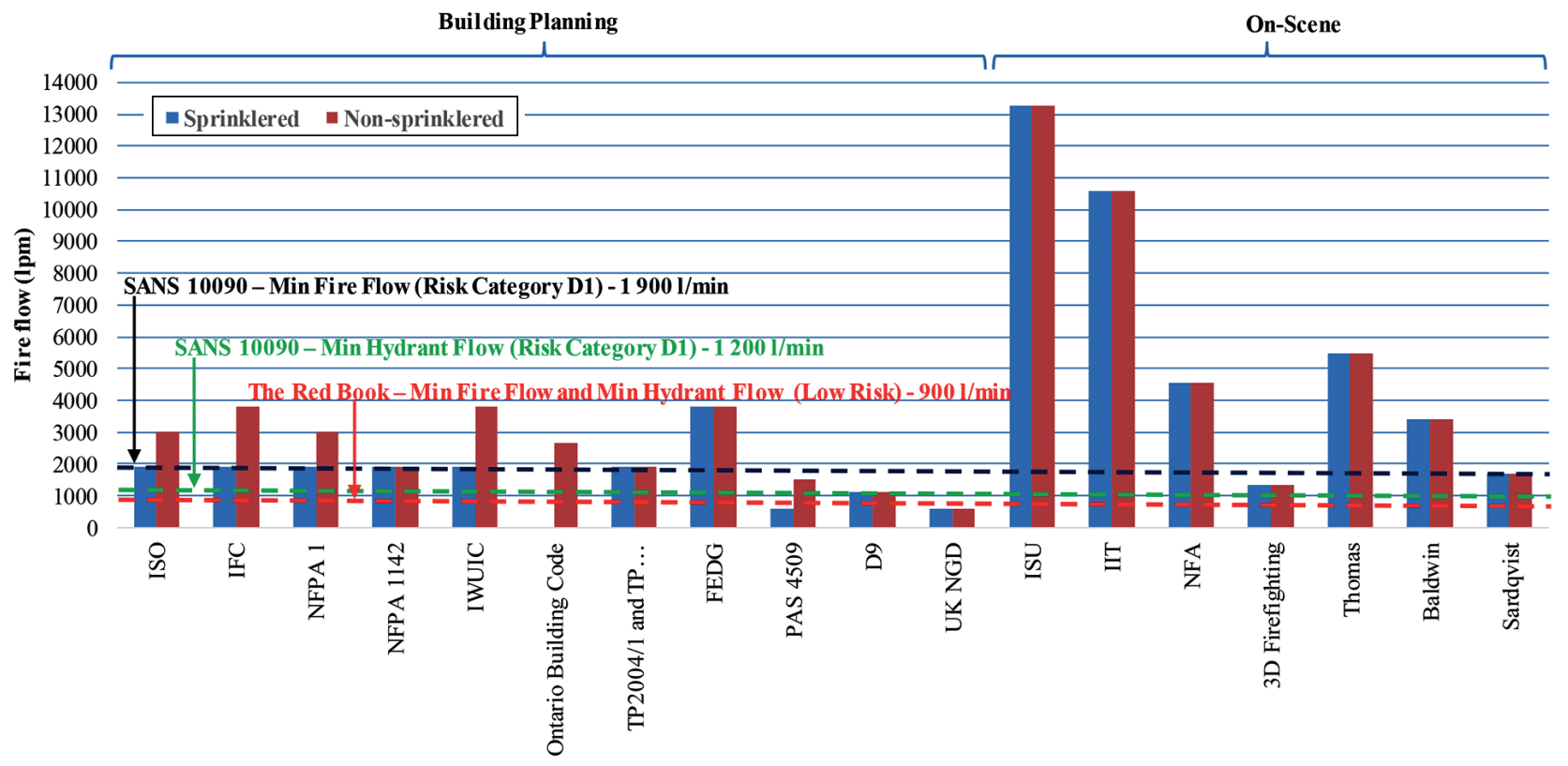

Figure 2. Fire flow requirements for a $3500 \mathrm{ft}^{2}\left(325 \mathrm{~m}^{2}\right)$ single-family home; sprinklered vs. non-sprinklered (Benfer and Scheffey, 2014) 
the total fire flow volume released during the incident. These calculations account for water obtained from fire trucks, water tankers, and hydrants.

The volume or flow rate is determined by reading the meters installed on each appliance. In this paper, the fire incident reports discussed are for fire incidents within the City of Johannesburg only and for the past 10 years (1 January 2006 to 30 September 2017).

Table 3 shows an example fire incident report which was used for invoicing purposes. In the table, it can be seen that 4 different stations responded to one emergency and a total of $30 \mathrm{~kL}$ of water was used for firefighting. The Malvern unit was on-site for the longest duration - $2 \mathrm{~h} 27 \mathrm{~min}$. It is assumed that fire flow rate extracted from the municipal network was constant over the on-site firefighting duration. While this assumption produces an average flow rate per incident (Eq. 1), it underestimates the peak firefighting flow (data which were not, and currently are not, recorded).

$$
\text { Average Fire Flow Rate }=\frac{\text { Total Fire Flow Volume }}{\text { Release Time-Arrival Time }}
$$

From 1 January 2006 to 30 September 2017, there were 4 556 billable firefighting incident reports recorded in the City of Johannesburg. Of this number, 697 were recorded as incidents that did not require municipal water and, therefore, the analysis below was based on 3859 billable water use incidents. This dataset excludes all non-billable fire incidents including informal settlements, veld/grass and car/motorcycle fires.

\section{RESULTS AND DISCUSSION}

The scatter plot shown in Fig. 3 shows the magnitude and distribution of the 3859 fire flow volumes recorded from 1 January 2006 to 30 September 2017. Figure 4 shows the magnitude and distribution of the 3859 fire flow rates from 1 January 2006 to 30 September 2017. To gauge the validity of the incidents with large fire flow volumes $(>300 \mathrm{~kL})$ and fire flow rates (>1000 L/min), fire event characteristics (such as duration, number of responding stations, presence of fire safety officials, and fire location) were individually examined. From this exercise, the fire incident circled in Figs 3 and 4 was identified as a likely data capture error because it did not bear the same characteristics as the other large fire volume incidents. The largest $(800 \mathrm{~kL})$ fire flow volume in the dataset was responded to by 6 different fire stations, lasted over $15 \mathrm{~h}$ and had fire safety officials present.

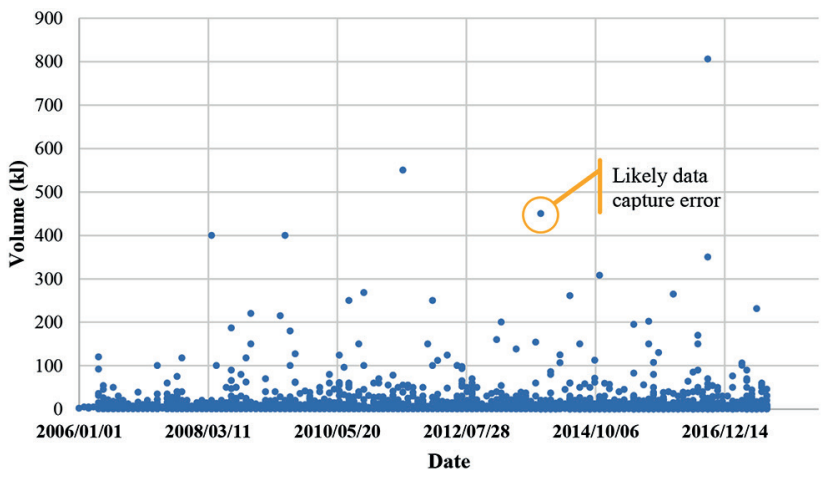

Figure 3. Fire flow volumes for billable incidents between 1 January 2006 and 30 September 2017

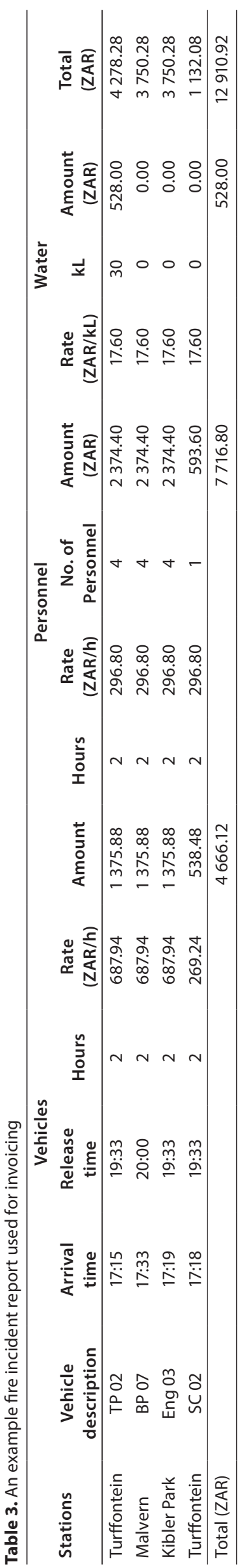


Figure 4 also includes the SANS 10090 (2003) standard and The Red Book (DHS and CSIR, 2019) guideline values for Fire Flow as well as the Minimum Hydrant Flow for the different fire risk categories. An assumption made in the below analysis is that the recorded firefighting flows extracted from the municipal network or fire equipment were what was required to fight the fires. None of the 3859 billable fire incident reports indicate otherwise.

Figure 4 reveals that over the 10 -year period, not a single fire incident in the City of Johannesburg recorded an average flow rate greater than $6000 \mathrm{~L} / \mathrm{min}$. This implies that over the 10 -year period, no incident can be classified as a SANS 10090 Category A, B or C nor The Red Book 'high risk' category fire. During the 10 -year period, only 2 incidents recorded average flow rates greater than $2000 \mathrm{~L} / \mathrm{min}$. Three incidents recorded average flow rates greater than $1500 \mathrm{~L} / \mathrm{min}$. The vast majority of average flow rates fell below both the SANS 10090 Minimum Hydrant Flow for Categories A, B, C and D and The Red Book Minimum Hydrant Flow for 'high risk' and 'moderate risk' categories.

Figure 5 shows that $75 \%$ of fire incidents were extinguished using less than $6.6 \mathrm{~kL}$ of water -this volume is less than the capacity $(6.9 \mathrm{~kL})$ of a conventional pumping tanker within the City of Johannesburg's fleet purchased in 2003. This means that over the study's 10 -year period, $75 \%$ of fire incidents in the City of Johannesburg could have been extinguished without the use of municipal fire hydrants if a pumping tanker with a full tank of water was dispatched. The below quote from Myburgh and Jacobs (2014 p.11) confirms similar results obtained for 3 municipal areas in the Western Cape: 'only $8.6 \%$ of all fires were extinguished using water from the WDS by connecting firefighting equipment to a fire hydrant at the time of the fire. Most fires were extinguished by means of water ejected from a pre-filled tanker vehicle disconnected from the WDS at the time of fighting the fire.'
Figure 6 presents the cumulative probability plot of average flow rates, with the SANS 10090 and The Red Book values superimposed. The figure shows that $99.9 \%$ of all fire incidents within the City during the designated period resulted in an average fire flow rate less than $1200 \mathrm{~L} / \mathrm{min}$, which equals the lowest of the Minimum Hydrant Flow rates for SANS 10090 (i.e. Category D). Likewise, $99.7 \%$ of all fire incidents resulted in an average fire flow rate less than $900 \mathrm{~L} / \mathrm{min}$, which equals the Minimuim Hydrant Flow rate for The Red Book's lowest fire risk category (i.e. low risk). These findings suggest that there is scope to reduce the current Minimum Fire Flows especially in low risk categories whilst maintaining adequate levels of safety. Because of the need to fight low probability but high consequence fires in moderate- to high-risk fire category areas, the authors caution on the application of the above statement to these areas.

To better understand intra-day and intra-year firefighting trends, Fig. 7 shows, over an average month, the average volume of water used to extinguish fires in relation to the

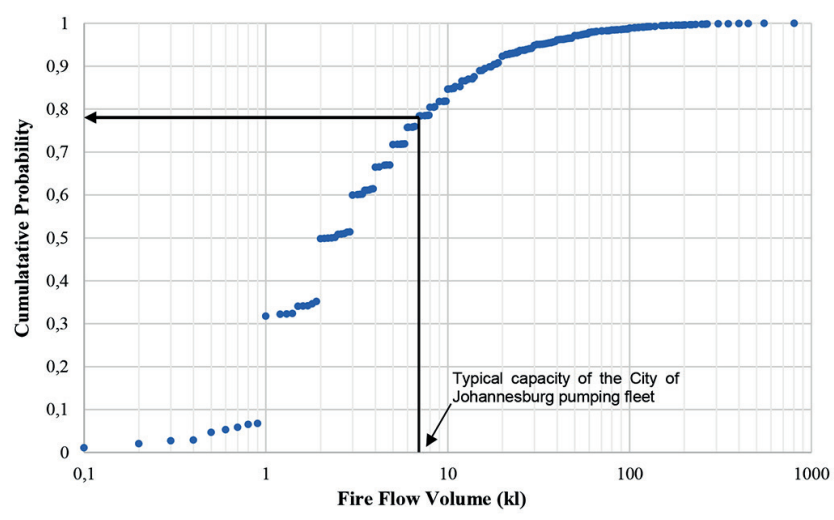

Figure 5. Cumulative probability plot for all fire flow volumes

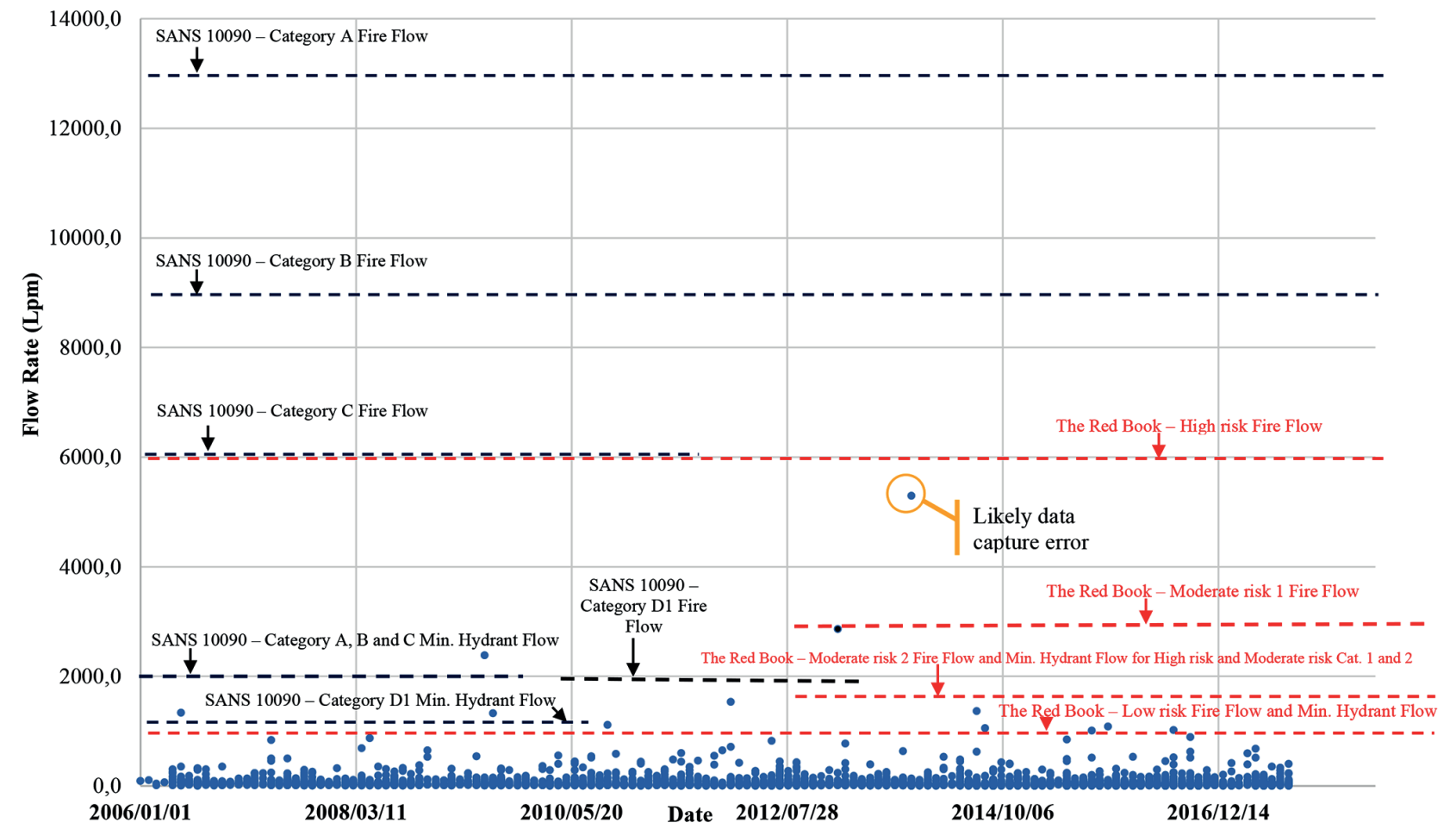

Figure 4. Average extracted fire flow rates for billable incidents between 1 January 2006 and 30 September 2017 


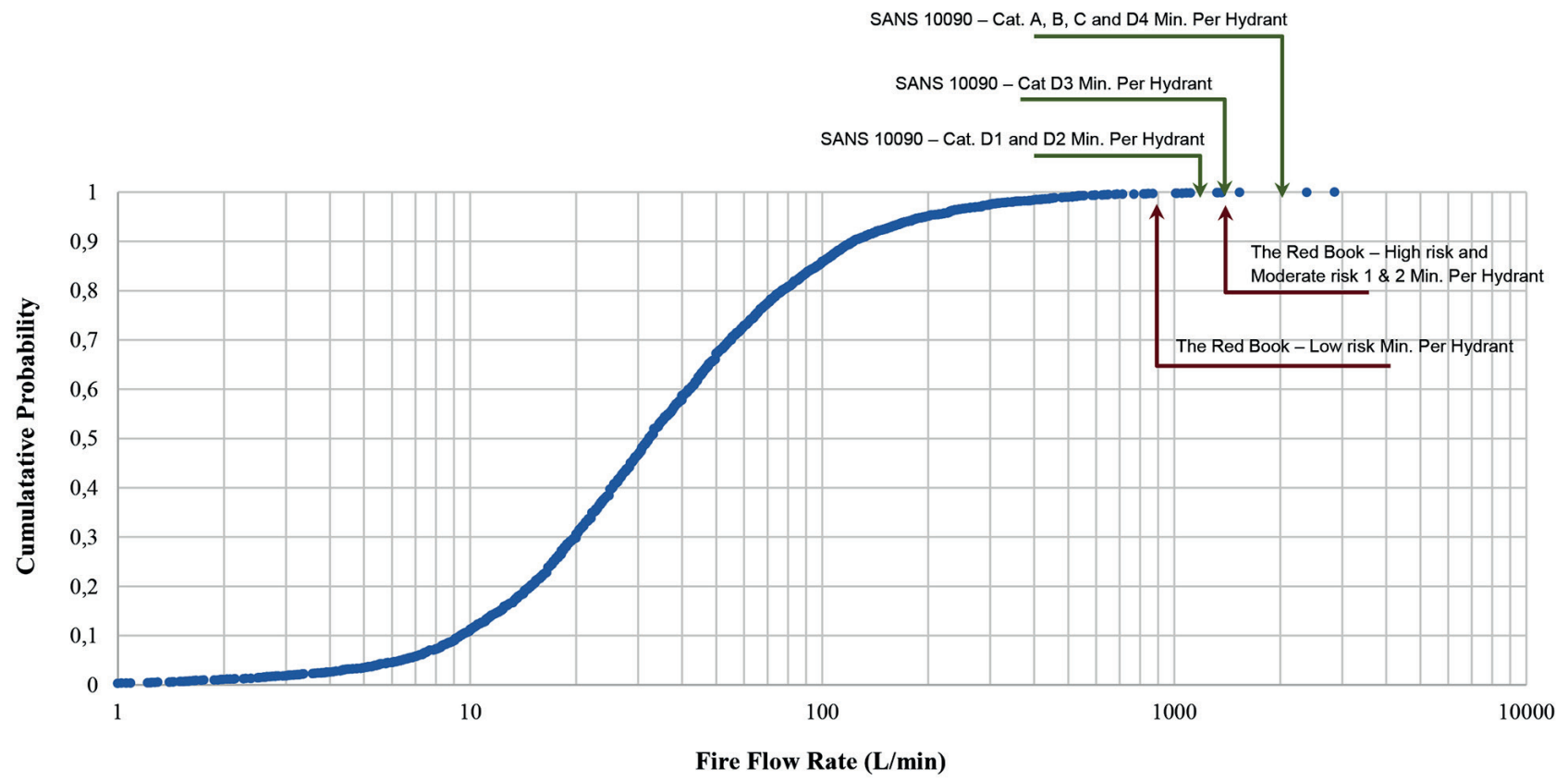

Figure 6. Cumulative probability plot for extracted fire flow rates within the City of Johannesburg (1 January 2006 to 30 September 2017 )

frequency of fire occurrence while Fig. 8 shows the frequency of occurrence of fires and residential water use over a typical day. In Fig. 7, the green bar chart shows the average number of fire incidents occurring each month while the blue bar chart shows the average fire flow volume per incident for each month over the period 1 January 2006 to 30 September 2017. An expected seasonal trend is observed with regard to frequency of fire occurrence, with a notable rise in incidents from June to October, which are typically dry and low-rainfall months in Johannesburg. While average fire flow volumes range between 7 to $12 \mathrm{~kL}$ per incident, there is no observable seasonal trend. These trends imply that, while the frequency of fire occurrence is strongly related to climatic conditions, the volume of water used to quench fires, and by implication, the size of the fires, is not a function of climatic conditions within the City of Johannesburg. As a consequence, seasonal peak factors for fire flows may not be necessary when incorporating the provision for water for firefighting in the design of municipal mains within the City of Johannesburg or other metropolitan municipalities with similar fire flow and climatic conditions.

Figure 8 displays the occurrence of incidents throughout the course of a day, averaged over the period 1 January 2006 to 30 September 2017. The green graph shows the percentage distribution of fire incident start times. In Fig. 8, three peaks (at 01:00, 15:00 and 20:00) are observed. The highest of the three was at 01:00 - this represents 230 (5.9\%) fire incidents. The blue graph shows a typical diurnal residential water use pattern published by Van Zyl (1996) (cited in Scheepers, 2012). The water use pattern shows the primary peak residential demand occurring at 06:00 while the secondary peak demand occurs between 16:00 and 17:00. When compared to the start times of fires within the City of Johannesburg, it is observed that the start times of peak fires do not correspond with peak residential water demand periods. The inverse is the case - the lowest observed start times of fires were during peak demand periods. This finding may therefore provide motivation to further investigate the recommendation to cater for both instantaneous

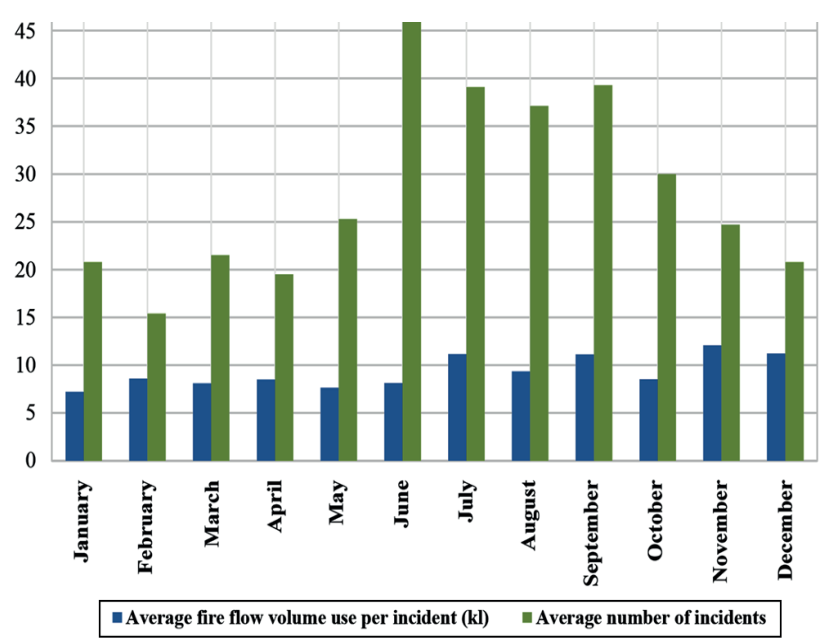

Figure 7. Average fire flow volume and number of incidents per month between 1 January 2006 and 30 September 2017

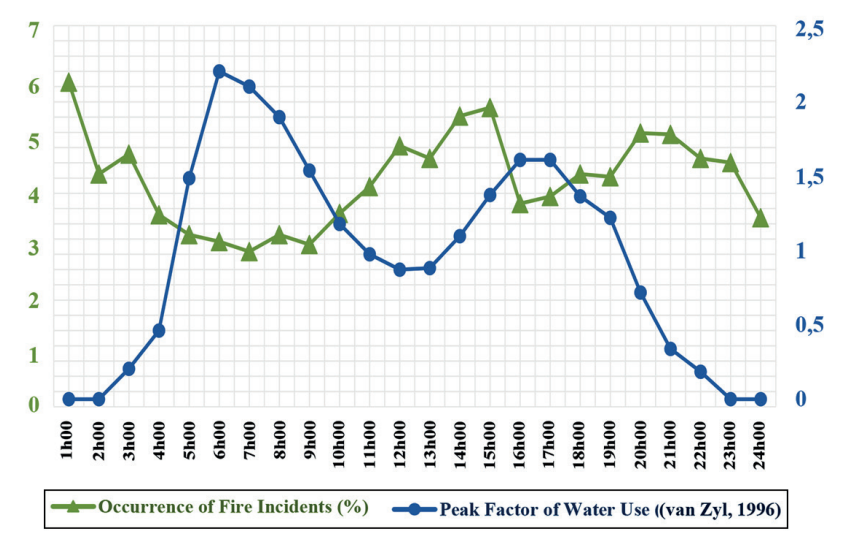

Figure 8. Occurrence of fires versus a typical residential peak water demand pattern 
peak demand and fire demand during WDS design as recommended by The Red Book (DHS and CSIR, 2019: J.3.2.2) i.e.: 'Conveyance infrastructure should have sufficient capacity for peak demand conditions and fire-flow requirements, in accordance with the design guidelines in this document' and (CSIR, 2005: volume 2, Chapter 9, page 27): 'The nominal capacity of the duty pump should be equivalent to the sum of the instantaneous peak demand and the fire demand (obtained from the section on provision of water for firefighting), or the instantaneous peak demand plus an allowance of $20 \%$, whichever is the greater.'

\section{CONCLUSIONS AND RECOMMENDATIONS}

The key results and recommendations arising from the two objectives addressed in this study are presented below:

- Objective 1: To present an analysis of international and South African design standards and guidelines pertaining to water provision for firefighting

- A review of national and international standards and guidelines for water provision for firefighting are presented in the text. A notable distinction between the SANS 10090 (SABS, 2003) standard and The Red Book (DHS and CSIR, 2019) guideline, apart from the different values they recommend for Fire Flow and Minimum Hydrant Flow, is their differing fire risk categories. The Red Book presents a single set of fire risk categories while SANS 10090 presents two fire risk categories which, in certain instances, do not recommend consistent fire flow values for the same category.

- In addition, The Red Book, which is a guideline, in all instances, violates the Minimum Fire Flows in SANS 10090, which is a standard that stipulates minimum acceptable values.

- It is therefore a recommendation of this paper that the SANS 10090 fire risk categories (A, B, C, D and E) be revised. As a result of their simplicity and recent revision, The Red Book (DHS and CSIR, 2019) fire risk categories may be adopted in the recommended revision of the SANS 10090 fire risk categories.

- Objective 2: To present actual fire flow data recorded in the City of Johannesburg, to compare this data with the primary South African standard and guideline values, and to make recommendations to guide future revisions to the primary South African design standard and guideline for the provision of water for firefighting.

- Fire incident reports were obtained from the City of Johannesburg's EMS for the period 1 January 2006 to 30 September 2017. These reports show that the majority of average fire flow rates fell below both the SANS 10090 (2003) and The Red Book (DHS and CSIR, 2019) Minimum Hydrant Flow for all its categories. The below highlights are evidence of this:

๑ Almost all (99.9\%) fire incidents recorded an average fire flow rate less than $1200 \mathrm{~L} / \mathrm{min}$ - the lowest Minimum Hydrant Flow rate for the SANS 10090 Categories

- Similarly, $99.7 \%$ of all fire incidents recorded an average extracted fire flow rate less than $900 \mathrm{~L} / \mathrm{min}$ - the lowest Minimuim Hydrant Flow rate for The Red Book's categories A second finding from the analysis of fire incident reports was that $75 \%$ of fire incidents were extinguished using less than $6.6 \mathrm{~kL}$ of water and thus could have been extinguished using one of the City of Johannesburg's conventional pumping tankers which have a capacity of $6.9 \mathrm{~kL}$. This, by implication, means that $75 \%$ of fire incidents within the City could have been extinguished without the use of municipal fire hydrants if a suitable tanker with a full tank of water was available.

- A third highlight was that, while the frequency of fire occurrence was strongly related to climatic conditions, the volume of water used to quench the fires was not a function of climatic conditions

- A fourth highlight was that the start times of peak fires did not correspond with peak residential water use periods within the City of Johannesburg over the 10 -year period. The inverse was however the case - the lowest observed fire incidents occurred during peak demand periods

Based on the above findings, and the assumption that the results from this study can be generically applied, the following recommendations can be made:

- A Minimum Hydrant Flow of $1200 \mathrm{~L} / \mathrm{min}$ is recommended for all SANS 10090 and The Red Book Categories. SANS 10252-1:2012 (SABS, 2012) stipulates the same value.

- To improve the efficiency of firefighting within the City of Johannesburg, especially considering the potential devastation that could occur due to increasing instances of water cuts and low pressures (Kahanji et al., 2019), EMS should focus on acquiring pumping appliances with sufficient capacity and volume (minimum of $6.6 \mathrm{~kL}$ ) to extinguish fires.

Based on the findings of this study, future research may investigate:

- The need for seasonal peak factors when incorporating the provision for water for firefighting in the design of municipal mains

- Catering for both instantaneous peak demand and fire demand during WDS design as recommended by The Red Book (DHS and CSIR, 2019)

- Understanding the change in rate of water use during a fire event

\section{AKNOWLEDGEMENTS}

The participation and data provided by the City of Johannesburg's Emergency Management Services personnel are gratefully acknowledged. Also gratefully acknowledged is the postgraduate funding and support by Mott MacDonald.

\section{REFERENCES}

BENFER M and SCHEFFEY J (2014) Evaluation of Fire Flow Methodologies. The Fire Protection Research Foundation, Quincy, Massachusetts. https://oi.org/10.1007/978-1-4939-2889-7

CSIR (2005) Guidelines for Human Settlement Planning and Design. Red Book. CSIR Building and Construction Technology, Pretoria.

DHS and CSIR (Department of Human Settlements, South Africa and Centre for Scientific and Industrial Research (2019) The Neighbourhood Planning and Design Guide (Red Book): Creating Sustainable Human Settlement. DHS and CSIR, Pretoria. ISBN 978-0-6399283-2-6.

DAVIS SK (2000) A review of fire fighting water requirements. ME thesis, University of Canterbury.

KAHANJI C, WALLS RS and CICIONE A (2019) Fire spread analysis for the 2017 Imizamo Yethu informal settlement conflagration in South Africa. Int. J. Disaster Risk Reduct. https://doi.org/10.1016/j. ijdrr.2019.101146

LAW M and BEEVER P (1995) Magic numbers and golden rules. Fire Saf. Sci. 4 79-84. https://doi.org/10.3801/IAFSS.FSS.4-79

MYBURGH HM and JACOBS HE (2014), Water for firefighting in five South African towns. Water SA 40 (1) 11-17. http://dx.doi. org/10.4314/wsa.v40i1.2 
RSA (Republic of South Africa) (1987) Fire Brigade Services Act. Act No. 99 of 1987. Government Gazette 11006, 23 October 1987, Issue 99. SABS (South African Bureau of Standards) (1972) SABS 090:1972. Community protection against fire. SABS, Pretoria.

SABS (South African Bureau of Standards) (2003) SANS 10090:2003 South African National Standard. Community protection against fire. Standards South Africa (a division of SABS), Pretoria. ISBN 0-626-14666-6

SABS (South African Bureau of Standards) (2012) SANS 10252-1:2012. South African National Standard. Water supply and drainage for buildings Part 1: Water supply installations for buildings. SABS Standards Division, Pretoria.

SCHEEPERS HM (2012) Deriving peak factors for residential indoor water demand by means of a probability based end-use model. Master of Science in Engineering, Stellenbosch University. SCHLOTFELDT CJ (1995) The "Red Book": Background, purpose and way forward. Paper presented at Red Book Workshops. February and March, Bloemfontein, Cape Town, Pretoria, Durban and Port Elizabeth.

VAN ZYL JE (1996) Peak factors in municipal water reticulation networks. Proceedings of the Water Institution of South Africa Biennial Conference and Exhibition, 20-23 May 1996, Port Elizabeth, South Africa.

VAN ZYL JE and HAARHOFF J (1997) South African fire water guidelines and their impact on water supply system cost. J. S. Afr. Inst. Civ. Eng. 39 (1) 16-22. 